Old Dominion University

ODU Digital Commons

OEAS Faculty Publications

Ocean, Earth \& Atmospheric Sciences

2009

\title{
Cross-Basin Comparison of Phosphorus Stress and Nitrogen Fixation in Trichodesmium
}

\author{
Annette M. Hynes \\ P. Dreux Chappell \\ Old Dominion University, pdchappe@odu.edu
}

Sonya T. Dyhrman

Scott C. Doney

Eric A. Webb

Follow this and additional works at: https://digitalcommons.odu.edu/oeas_fac_pubs

Part of the Marine Biology Commons, and the Oceanography Commons

\section{Repository Citation}

Hynes, Annette M.; Chappell, P. Dreux; Dyhrman, Sonya T.; Doney, Scott C.; and Webb, Eric A., "Cross-Basin Comparison of Phosphorus Stress and Nitrogen Fixation in Trichodesmium" (2009). OEAS Faculty Publications. 204.

https://digitalcommons.odu.edu/oeas_fac_pubs/204

\section{Original Publication Citation}

Hynes, A. M., Chappell, P. D., Dyhrman, S. T., Doney, S. C., \& Webb, E. A. (2009). Cross-basin comparison of phosphorus stress and nitrogen fixation in Trichodesmium. Limnology and Oceanography, 54(5), 1438-1448. doi:10.4319/lo.2009.54.5.1438

This Article is brought to you for free and open access by the Ocean, Earth \& Atmospheric Sciences at ODU Digital Commons. It has been accepted for inclusion in OEAS Faculty Publications by an authorized administrator of ODU Digital Commons. For more information, please contact

digitalcommons@odu.edu. 


\title{
Cross-basin comparison of phosphorus stress and nitrogen fixation in Trichodesmium
}

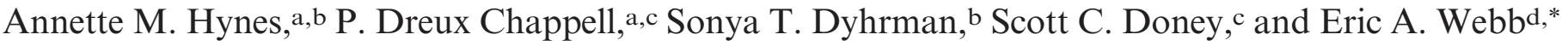 \\ a MIT-WHOI Joint Program in Oceanography/Applied Ocean Science and Engineering, Woods Hole Oceanographic Institution, \\ Woods Hole, Massachusetts \\ b Department of Biology, Woods Hole Oceanographic Institution, Woods Hole, Massachusetts \\ c Department of Marine Chemistry and Geochemistry, Woods Hole Oceanographic Institution, Woods Hole, Massachusetts \\ d Department of Biology, University of Southern California, Los Angeles, California
}

\begin{abstract}
We investigated the phosphorus (P) status and $\mathrm{N}_{2}$ fixation rates of Trichodesmium populations from the North Pacific, western South Pacific, and western North Atlantic. Colonies of Trichodesmium were collected and analyzed for endogenous alkaline phosphatase (AP) activity using enzyme-labeled fluorescence (ELF) and for nitrogenase activity using acetylene reduction. AP hydrolyzes dissolved inorganic phosphate (DIP) from dissolved organic phosphorus and is active in Trichodesmium colonies experiencing P stress. Across multiple stations in the subtropical North and South Pacific, there was low to moderate ELF labeling in Trichodesmium, although labeling was present in other taxa. In contrast, Trichodesmium ELF labeling in the North Atlantic ranged from low to high. Low ELF labeling corresponded with high DIP concentrations while high ELF labeling occurred only at North Atlantic stations with DIP concentrations $\leq 40 \mathrm{nmol} \mathrm{L}-1$, indicating that Trichodesmium was not experiencing dramatic P stress in the Pacific Ocean while P stress was evident in the western North Atlantic. However, nitrogenase activity was significantly higher in the P-stressed western North Atlantic than in the Pacific Ocean (0.40-1.30 compared to $0.01-0.46 \mathrm{nmol} \mathrm{C}_{2} \mathrm{H}_{4} \mathrm{~h}^{-1}$ colony $\left.{ }^{-1}\right)$. These data underscore the differential basinlevel importance of $\mathrm{P}$ availability to Trichodesmium and suggest that factors other than $\mathrm{P}$ are constraining their $\mathrm{N}_{2}$ fixation rates in the Pacific.
\end{abstract}

Fixed nitrogen $(\mathrm{N})$ is considered to be the proximal limiting nutrient in ocean ecosystems. For a system in steady-state, new production is the excess production available for export and is a function of new $\mathrm{N}$ entering the system and stimulating production (Eppley and Peterson 1979). New N comes from eddy-diffusion processes, seasonal deep mixing, atmospheric deposition, lateral advection, and $\mathrm{N}_{2}$ fixation by diazotrophs (Dugdale and Goering 1967). Upwelled water from the deep ocean contains both elevated dissolved inorganic nitrogen (DIN) and dissolved inorganic carbon (DIC), so export production from upwelled DIN does not generally result in a significant net removal of DIC from surface water. However, DIN from $\mathrm{N}_{2}$ fixation is not related to the DIC supply from deep water and can drive uptake of $\mathrm{CO}_{2}$ and export production (Hood et al. 2000). In global marine models, the presence of $\mathrm{N}_{2}$-fixers increased primary production by diatoms and small phytoplankton through the excretion of dissolved organic nitrogen (DON) in Nlimited areas (Moore et al. 2004). In the subtropical Atlantic, model results show that $\mathrm{N}_{2}$ fixation increases DIN, phytoplankton biomass, primary production, and export flux (Coles et al. 2004).

The cyanobacterium Trichodesmium is an important source of new $\mathrm{N}$ in tropical and subtropical oceans (Capone et al. 1997). In the North Atlantic, $\mathrm{N}_{2}$ fixation rates of Trichodesmium can equal or exceed the vertical flux of nitrate into surface waters (Capone et al. 2005), while in the North Pacific, $\mathrm{N}_{2}$ fixation is the source of up to half of the new N (Karl et al. 1997). Global ecosystem models use

\footnotetext{
* Corresponding author: eawebb@usc.edu
}

parameters from Trichodesmium to model $\mathrm{N}_{2}$ fixation (Coles et al. 2004; Moore et al. 2004; Moore and Doney 2007). Elucidating the factors limiting the growth and $\mathbf{N}_{2}$ fixation rates of Trichodesmium is vital to understanding the $\mathrm{N}$ cycle and its link to the carbon cycle.

$\mathrm{N}_{2}$ fixation by Trichodesmium can be limited by a variety of factors including light, temperature, mixed-layer depth, dissolved oxygen, and nutrients such as phosphorus $(\mathrm{P})$ and iron (Fe) (Wu et al. 2000; Moore et al. 2004). Like N, new P can reach the surface by mixing, upwelling from deep waters, lateral advection, or deposition; however, there is no process analogous to $\mathrm{N}_{2}$ fixation to act as a source for bioavailable P (Karl 2002). Nitrogenase, the enzyme responsible for $\mathrm{N}_{2}$ fixation, requires multiple $\mathrm{Fe}$ atoms per molecule. Sources of $\mathrm{Fe}$ to open-ocean environments are dust deposition, advection from continental margins, and upwelling (Fung et al. 2000). Due to these obligate requirements and low oceanic concentrations, $\mathrm{P}$ and $\mathrm{Fe}$ bioavailability may influence the growth and $\mathrm{N}_{2}$ fixation rates of Trichodesmium field populations (Berman-Frank et al. 2001; Sañudo-Wilhelmy et al. 2001). In the central Atlantic, $\mathrm{N}_{2}$ fixation positively correlated to the $\mathrm{P}$ content of Trichodesmium (Sañudo-Wilhelmy et al. 2001) while in the eastern tropical Atlantic, $\mathrm{N}_{2}$ fixation was co-limited by $\mathrm{P}$ and $\mathrm{Fe}$ (Mills et al. 2004). In the North Pacific Subtropical Gyre (NPSG), P supply may be the ultimate control on new and export production at Sta. ALOHA (Karl et al. 1997), but Fe rather than $\mathrm{P}$ is likely to limit $\mathrm{N}_{2}$ fixation (Wu et al. 2000).

Although subtropical gyres of both the North Pacific and the North Atlantic are oligotrophic, the NPSG has higher dissolved inorganic phosphate (DIP) concentrations: 

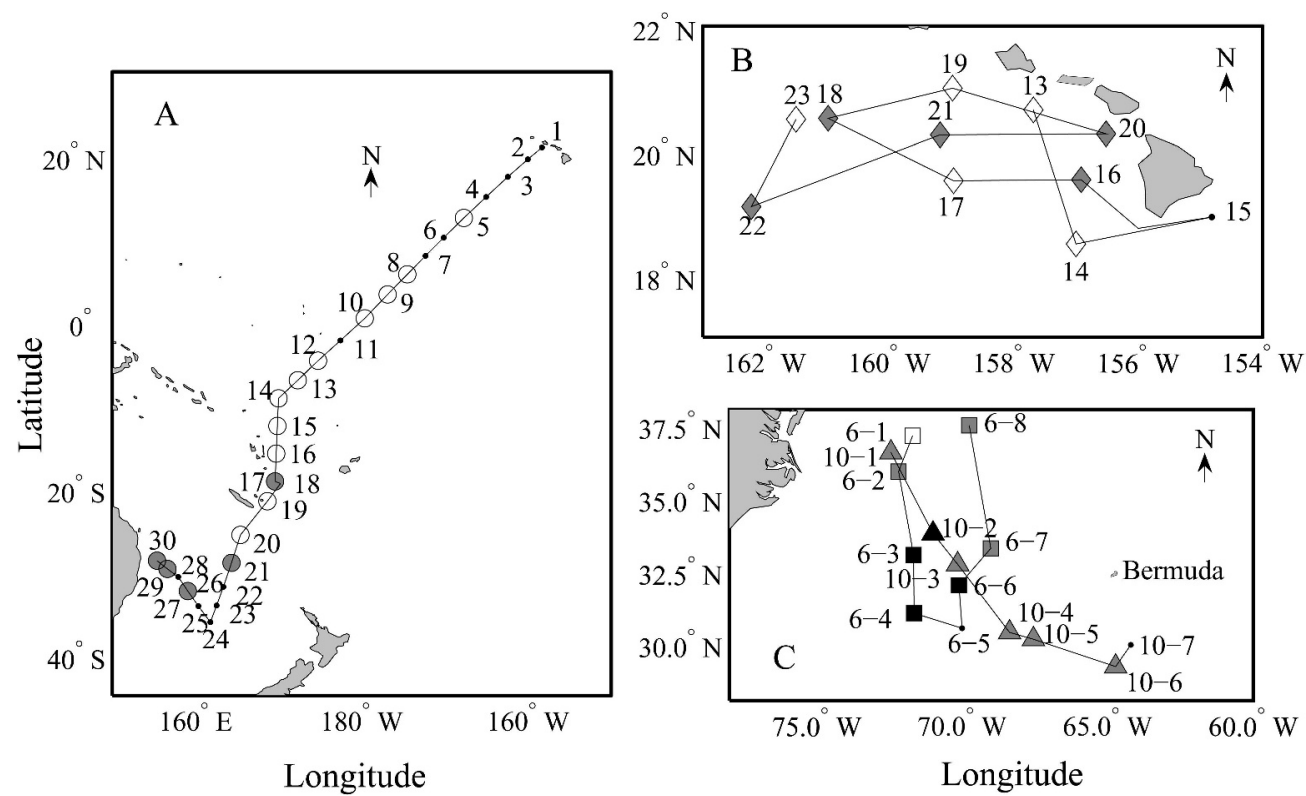

Fig. 1. Maps of cruise tracks: (A) KM0701 (circles) during January and February 2007, across the west Pacific warm pool; (B) MP09 (diamonds) during August 2003, in the North Pacific; (C) EN355 (squares) during June 2001, and EN361 (triangles) during October 2001, in the western North Atlantic. The highest level of ELF labeling for all colony types at each station is indicated by color: black symbols $=$ ' ++ ', gray symbols $=$ ' +- ', open symbols $=$ ' - -', small dots $=$ no ELF data.

$3.0-191.3 \mathrm{nmol} \mathrm{L}^{-1}$ in the NPSG compared to $0.2-$ $1.0 \mathrm{nmol} \mathrm{L}-1$ in the North Atlantic (Hawaii Ocean Timeseries [HOT], http://hahana.soest.hawaii.edu/hot/hot_jgofs. html; Wu et al. 2000). Dissolved organic and particulate pools of $\mathrm{P}$ are also higher in the NPSG than the North Atlantic (Ammerman et al. 2003). In the western South Pacific, DIP concentrations ranged from $80 \mathrm{nmol} \mathrm{L}^{-1}$ to $218 \mathrm{nmol} \mathrm{L}^{-1}$ in oceanic regions (Campbell et al. 2005) and from $<30 \mathrm{nmol} \mathrm{L}^{-1}$ to $63 \mathrm{nmol} \mathrm{L}-1$ near New Caledonia (Van Den Broeck et al. 2004). P limitation may be related to inputs of $\mathrm{Fe}$ (Wu et al. 2000). The NPSG has lower aeolian Fe input than the subtropical North Atlantic: 0.08$0.16 \mu \mathrm{mol} \mathrm{Fe} \mathrm{m}{ }^{-2} \mathrm{~d}^{-1}$ compared to $0.2-0.8 \mu \mathrm{mol} \mathrm{Fe}$ $\mathrm{m}^{-2} \mathrm{~d}^{-1}$, respectively ( $\mathrm{Wu}$ et al. 2000). Open-ocean dissolved-Fe concentrations in the upper $100 \mathrm{~m}$ averaged 720 pmol L-1 in the North Atlantic, $200 \mathrm{pmol} \mathrm{L}^{-1}$ in the North Pacific, and $110 \mathrm{pmol} \mathrm{L}^{-1}$ in the Equatorial Pacific (Moore and Braucher 2008). During a cruise in the western South Pacific, open-ocean dissolved-Fe concentrations ranged from $<60 \mathrm{pmol} \mathrm{L}^{-1}$ to $760 \mathrm{pmol} \mathrm{L}^{-1}$ while coastal dissolved-Fe concentrations ranged from $<60 \mathrm{pmol} \mathrm{L}^{-1}$ to $1000 \mathrm{pmol} \mathrm{L}^{-1}$ (Campbell et al. 2005). In addition to low concentrations, bioavailability of $\mathrm{Fe}$ and $\mathrm{P}$ can limit abundance and activity of Trichodesmium, and differences in the availability of these nutrients across ocean basins create a variety of limitation scenarios.

Herein we define nutrient stress as the exposure of a cell to low inorganic nutrient conditions that stimulates a response from the cell. Phytoplankton can launch a physiological response under conditions of $\mathrm{P}$ stress to ameliorate potential limitation. DIP is the most readily available form of phosphorus. The utilization of dissolved organic phosphorus
(DOP) can prevent limitation of Trichodesmium growth and $\mathrm{N}_{2}$ fixation rates in low-DIP environments. However, accessing the DOP pool requires the cell to invest energetic, carbon, and nitrogen resources in enzymes such as alkaline phosphatase (AP). We define this as distinct from $\mathrm{P}$ limitation, which is the reduction of either growth or $\mathrm{N}_{2}$ fixation rates as a result of persistent stress. AP hydrolyzes DIP from DOP and is commonly induced in phytoplankton species experiencing P stress (Stihl et al. 2001; Dyhrman et al. 2002). DOP is likely a significant source of $P$ for Trichodesmium spp. (Sohm and Capone 2006; Mather et al. 2008), and the presence of AP activity can indicate Trichodesmium field populations responding to low levels of DIP (Stihl et al. 2001). AP activity can be measured using colorimetric and fluorometric assays or detected through molecular diagnostic tools. Enzyme-labeled fluorescence (ELF) is a commercially available, cell-specific molecular diagnostic tool that detects AP activity. The phosphatase substrate precipitates when cleaved by AP and fluoresces green under ultraviolet light (González-Gil et al. 1998). In the laboratory, P-depleted Trichodesmium erythraeum IMS101 batch cultures were ELF-labeled while replete cultures were not (Dyhrman et al. 2002). In shipboard incubations, addition of DIP to ELF-positive populations of Trichodesmium reduced ELF labeling within $48 \mathrm{~h}$ (Webb et al. 2007). We believe that ELF labeling of P-stressed Trichodesmium gives valuable insight into the in situ physiological status of the cells.

In this study we compare Trichodesmium $\mathrm{P}$ stress and nitrogenase activity among tropical and subtropical regions of the western North Atlantic, the North Pacific, and the western South Pacific (Fig. 1). We collected colonies of 
Trichodesmium from four cruises and analyzed endogenous AP activity using ELF, measured nitrogenase activity using acetylene reduction, and sampled surface water nutrients to assess the $\mathrm{P}$ status of Trichodesmium populations. Our results show that populations in the western North Atlantic were more $\mathrm{P}$ stressed but had higher nitrogenase activities than populations in the North and South Pacific.

\section{Methods}

Hydrological context-Samples were collected along a north-south transect of the Pacific Ocean as part of the Western Pacific Warm Pool cruise (KM0701) on the R/V Kilo Moana in January-February 2007 (Fig. 1A). As part of the Marine Nitrogen Transformation Biocomplexity Project, samples were taken from south of Hawaii during MP09 in August 2003, on the R/V Revelle (Fig. 1B). North Atlantic field samples were collected near the Bermuda Atlantic Time-series Station in June and October 2001, aboard the R/V Endeavor (EN355 and EN361, respectively; Fig. 1C). Temperature, salinity, pressure, and density data from each cruise were obtained from a conductivitytemperature-depth (CTD) system. Mixed-layer depths (MLD) were estimated from potential density profiles. Sea surface temperature (SST) and salinity were obtained from the ships' underway data.

Collection of colonies-A $0.5-\mathrm{m}$-diameter, $130.0-\mu \mathrm{m}$ mesh phytoplankton net with a $30-\mathrm{m}$ line was hand-towed for 10-20 min. Tows for ELF were typically done in the morning while tows for nitrogenase activity were done around noon, the peak of $\mathrm{N}_{2}$ fixation in Trichodesmium, targeting local times of 11:00 h, 12:00 h, and 13:00 h. Specimens were immediately shaded and taken into an airconditioned laboratory. Colonies of Trichodesmium spp. were collected with polyethylene bulb pipets or plastic bacteriological transfer loops (Fisher Scientific); separated by colony morphology into spherical 'puffs', fusiform 'tufts', and occasionally 'bowties'; and washed four times in sterilized seawater $(0.2-0.4-\mu \mathrm{m}$-filtered and microwaved to a rolling boil). The colonies were processed immediately for AP or nitrogenase activity. Stations with no data reported had too little Trichodesmium biomass to run the assays.

Enzyme-labeled fluorescence (ELF)-The presence of AP activity was determined using the ELF 97 Endogenous Phosphatase Detection Kit (Molecular Probes-Invitrogen) following the improved protocol described in Dyhrman et al. (2002) for two colonies of each morphology. The slides were stored damp and in the dark at $4{ }^{\circ} \mathrm{C}$. ELF slides were viewed with epifluorescent microscopy using a 4, 6diamidino-2-phenyl-indole (DAPI) long-pass filter set $(360 \mathrm{~nm})$. The entire area of the slide was examined. Digital pictures of Trichodesmium from MP09 and the Atlantic cruises were taken at $200 \times$ using a Zeiss Axioplan2 microscope equipped with a Zeiss Axiocam digital camera and Openlab software (Improvision). Digital pictures from KM0701 were taken at $400 \times$ using a Zeiss Axiostar microscope equipped with a MRC5 Axiocam and Axiovision software (Zeiss). Samples were rated '- -' for 'no labeling,' '+ -' for 'some labeling' if many filaments showed moderate labeling but were not wholly covered or if there was mixture of labeled and unlabeled filaments, and ' + +' for 'high labeling' if many filaments showed dense labeling and/or were wholly covered. For the North Atlantic samples, multiple slides were made for each colony type so one rating was given based on all the slides. Filament color was noted as 'normal' if the orange color of the phycoerythrin autofluorescence was visible or 'dim' if the filaments appeared abnormally dark, green or blue. Digital pictures of pennate diatoms associated with Trichodesmium colonies were taken at $400 \times$ with the DAPI long-pass filter and a chlorophyll filter $(660 \mathrm{~nm})$ using AxioVision 4.2 software.

Nutrient analysis-For the North and South Pacific (KM0701) and the North Atlantic (EN355 and EN361), surface water was collected using either niskin bottles from a rosette or Go-Flo bottles, filtered through acid-cleaned $0.4-\mu \mathrm{m}$ polycarbonate filters, and frozen. Samples for KM0701 were sent to the College of Oceanic and Atmospheric Sciences, Oregon State University and DIP was analyzed using a Technicon AutoAnalyzer II by J. Jennings with a detection level of $6 \mathrm{nmol} \mathrm{L}^{-1}$. North Atlantic samples were sent to the Ocean Data Facility of the Scripps Institution of Oceanography (http://sts.ucsd. edu/sts/chem) for analysis by a Skalar San Plus autoanalyzer with a detection level of $3 \mathrm{nmol} \mathrm{L}^{-1}$. DIP concentrations for the North Pacific during MP09 were provided by K. Björkman (pers. comm.). Two-way ANOVA TukeyKramer tests were used to determine significant differences in DIP concentrations among ELF ratings and oceans for stations with both DIP concentrations and ELF samples $(\alpha$ $=0.05)$. DIP concentrations below detection level (BDL) were considered to be 0 in the calculations.

Nitrogenase activity-Nitrogenase activity was assayed during KM0701 and the Atlantic cruises by the acetylene reduction assay described by Capone and Montoya (2001). Five to twenty colonies were placed in $20-30 \mathrm{~mL}$ of $0.2-$ $\mu \mathrm{m}$-filtered seawater in $75-\mathrm{mL}$ square polycarbonate culturing bottles with silicone septa. Two to three replicate bottles were used for each incubation. Acetylene was produced on board by mixing $50 \mathrm{~mL}$ of double-distilled water with $15 \mathrm{~g}$ calcium carbide and stored in a bladder. Six $\mathrm{mL}$ of acetylene were injected into the bottles. The bottles were incubated in a Percival incubator at ambient surface seawater temperatures under soft white fluorescent bulbs at $50-\mu \mathrm{mol}$ quanta $\mathrm{m}^{-2} \mathrm{~s}^{-1}$ light. Zero times were targeted at 11:00 h, 12:00 h, and 13:00 h, local time. At times $0,1 \mathrm{~h}$, and $2 \mathrm{~h}$ after injection, duplicate $0.2-0.3-\mathrm{mL}$ samples were removed from the headspace of the bottles and injected into a Shimadzu GC-8A gas chromatograph and integrated by a Shimadzu CR8A Chromatopac to measure the ethylene peaks. Standards of $9.1-\mu \mathrm{L} \mathrm{L}^{-1}$ ethylene were used to calibrate the peak heights. Ethylene formed was calculated according to Capone and Montoya (2001) with Bunsen coefficients calculated from surface salinity and temperature according to Breitbarth et al. (2004). Nitrogenase activity was calculated as the average 


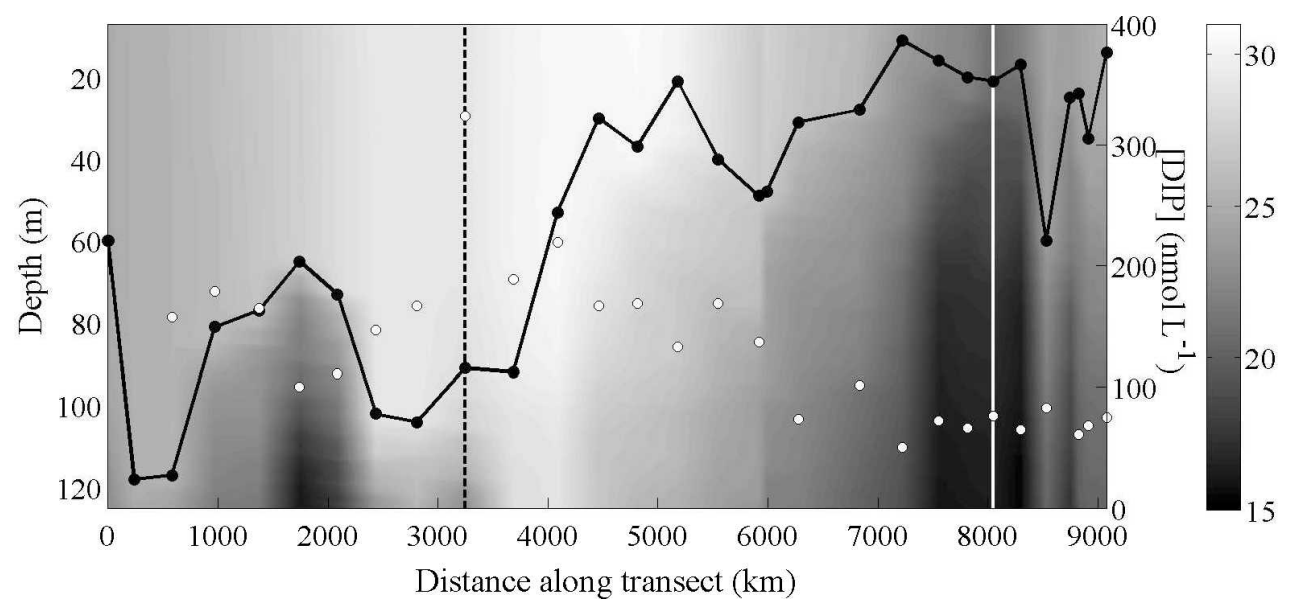

Fig. 2. Hydrographic conditions of KM0701. The grayscale pseudo-color plot is potential temperature $\left({ }^{\circ} \mathrm{C}\right)$ as a function of depth $(\mathrm{m})$ vs. distance along the transect $(\mathrm{km})$ starting from Hawaii, U.S.A. The connected black circles are mixed-layer depth (m) while the white circles indicate DIP concentrations $\left(\mathrm{nmol} \mathrm{L}{ }^{-1}\right)$. The vertical dashed black line represents the Equator and the vertical solid white line denotes a turning point in the transect.

rate of ethylene production per colony (nmol $\mathrm{C}_{2} \mathrm{H}_{4} \mathrm{~h}^{-1}$ colony ${ }^{-1}$ ). Acetylene reduction rates for MP09 were provided by D. Capone (pers. comm.). One-way ANOVA Tukey-Kramer tests were used to determine statistically different rates between colony morphologies and among the cruise means $(\alpha=0.05)$.

\section{Results}

Physical conditions - The North Atlantic upper ocean was stratified with late-spring SST ranging from $23^{\circ} \mathrm{C}$ to $25^{\circ} \mathrm{C}$ and MLD ranging from $4 \mathrm{~m}$ to $37 \mathrm{~m}$ during EN355 and autumn SST ranging from $25^{\circ} \mathrm{C}$ to $28^{\circ} \mathrm{C}$ and MLD ranging from $70 \mathrm{~m}$ in the northern part of the transect to $26 \mathrm{~m}$ in the south during EN361. During MP09, the summer North Pacific upper ocean was highly stratified with SST ranging from $26.5^{\circ} \mathrm{C}$ to $27.5^{\circ} \mathrm{C}$ and MLD ranging from $25 \mathrm{~m}$ to $58 \mathrm{~m}$. KM0701 cut across the west Pacific warm pool, with early winter deep mixing up to $118 \mathrm{~m}$ in the north, early summer stratification as shallow as $11 \mathrm{~m}$ in the south, and a maximum SST of $>30^{\circ} \mathrm{C}$ just south of the Equator (Fig. 2). As the MLD shoaled in the southern end of the west Pacific transect, DIP concentrations decreased (Fig. 2).

$E L F$ - North Atlantic samples consistently showed more ELF labeling than Pacific samples. A spatial representation of the maximum ELF labeling at each station is shown along the cruise tracks in Fig. 1. During the timeframe of this study, North and South Pacific Trichodesmium field samples did not show high ELF labeling. All samples were rated ' +- ' or ' - -', indicating that there was low to no AP activity (Table 1; Figs. 1A,B; 3A-H). Labeling of South Pacific Trichodesmium colonies was highest on the shelf near Australia at ' +- ' (Fig. 1A). In contrast, North Atlantic ELF samples ranged from ' - -' to ' + +' (Table 1; Figs. 1C, 3I-P). Labeling of the two colony morphologies was not always at the same level, as seen at Sta. 16, 18, and
20 of MP09 (Table 1; Fig. 3A,B) and Sta. 14, 26, and 29 of KM0701 (Table 1; Fig. 3G,H). Labeling of colonies at the same station on different days could vary, as seen at MP09 Sta. 17 and 22 (Table 1; Fig. 3C,D) and KM0701 Sta. 14 (Table 1). Two colonies on the same slide could also differ. For example, Sta. 7 and 8 from EN355 had some highly labeled filaments among unlabeled filaments, giving the slides a rating of ' +- ' (Fig. 3J-L). Although Trichodesmium colonies collected were identified by morphology, two to three different filament sizes were observed in over half of the samples (Fig. 3L). Color from the autofluorescence of phycoerythrin in the filaments varied, ranging from the usual orange color (Table 1; Fig. 3A,B, E-H) to a dim green or blue (Table 1; Fig. 3C,D,J).

In spite of efforts to wash the colonies for the ELF assay, a variety of microbes were found in association with Trichodesmium colonies including diatoms, heterotrophic bacteria, and the filamentous $\mathrm{N}_{2}$-fixing cyanobacteria Plectonema sp. and Calothrix sp. (Fig. 4A-E). As in Dyhrman et al. (2002), some of these organisms were found to be ELF-labeled even when Trichodesmium was not, indicating AP activity in these other taxa: diatoms (North Pacific MP09-21, North Atlantic EN361-1; Fig. 4A-B), heterotrophic bacteria (over half of the stations on all four cruises; Fig. 4C), and Plectonema sp. (North Pacific MP09-19, North Atlantic EN361-1, 2, 3; Fig. 4D). Calothrix sp. was found in association with Trichodesmium near Hawaii during MP09 and was not ELF-labeled (Sta. 13, 17, 18, 19, 21, 23; Fig. 4E).

$D I P$ and $E L F$-ELF labeling varied with ocean basin and corresponded negatively with DIP concentrations. North Atlantic stations had significantly lower DIP concentrations than the North and South Pacific stations in a two-way ANOVA $(p=0.0001$; Table 2). DIP concentrations ranged from $\mathrm{BDL}$ to $25 \mathrm{nmol} \mathrm{L}^{-1}$ in the North Atlantic, 30-320 nmol L ${ }^{-1}$ in the North Pacific, and 50-220 nmol L ${ }^{-1}$ in the South Pacific. Stacked histograms 
Table 1. Data summary for stations with enzyme-labeled fluorescence (ELF) data. For stations with multiple colony morphologies, data are separated by ' $\%$. NA $=$ not available.

\begin{tabular}{|c|c|c|c|c|c|c|}
\hline Date & Station & Latitude & Longitude & Colony & ELF & Color \\
\hline 01 Jun 01 & EN355-1 & $37^{\circ} 6^{\prime} \mathrm{N}$ & $71^{\circ} 42^{\prime} \mathrm{W}$ & puff/tuft & $--1--$ & $\operatorname{dim} / \operatorname{dim}$ \\
\hline 02 Jun 01 & EN355-2 & $35^{\circ} 52^{\prime} \mathrm{N}$ & $71^{\circ} 43^{\prime} \mathrm{W}$ & puff & +- & $\operatorname{dim}$ \\
\hline 03 Jun 01 & EN355-3 & $33^{\circ} 0^{\prime} \mathrm{N}$ & $71^{\circ} 40^{\prime} \mathrm{W}$ & puff & ++ & $\operatorname{dim}$ \\
\hline 04 Jun 01 & EN355-4 & $31^{\circ} 33^{\prime} \mathrm{N}$ & $71^{\circ} 39^{\prime} \mathrm{W}$ & puff/tuft & $++/+-$ & $\operatorname{dim} / \operatorname{dim}$ \\
\hline 05 Jun 01 & EN355-5 & $30^{\circ} 29^{\prime} \mathrm{N}$ & $70^{\circ} 0.0^{\prime} \mathrm{W}$ & puff/bowtie & NA/NA & NA/NA \\
\hline 07 Jun 01 & EN355-6 & $32^{\circ} 2.4^{\prime} \mathrm{N}$ & $70^{\circ} 19.51^{\prime} \mathrm{W}$ & NA & ++ & dim-normal \\
\hline 09 Jun 01 & EN355-7 & $33^{\circ} 16.67^{\prime} \mathrm{N}$ & $68^{\circ} 59.32^{\prime} \mathrm{W}$ & NA & +- & dim-normal \\
\hline 11 Jun 01 & EN355-8 & $37^{\circ} 27.32^{\prime} \mathrm{N}$ & $69^{\circ} 45.28^{\prime} \mathrm{W}$ & NA & +- & dim-normal \\
\hline 04 Oct 01 & EN361-1 & $36^{\circ} 31.53^{\prime} \mathrm{N}$ & $72^{\circ} 26.78^{\prime} \mathrm{W}$ & puff/tuft & $+-1+-$ & dim-normal/normal \\
\hline 05 Oct 01 & EN361-2 & $33^{\circ} 44.52^{\prime} \mathrm{N}$ & $70^{\circ} 59.79^{\prime} \mathrm{W}$ & puff/tuft & $--1+-$ & dim-normal/dim-normal \\
\hline 05 Oct 01 & EN361-3 & $32^{\circ} 40.89^{\prime} \mathrm{N}$ & $70^{\circ} 9.3^{\prime} \mathrm{W}$ & puff/tuft & $+-1+-$ & dim-normal/dim-normal \\
\hline 06 Oct 01 & EN361-4 & $30^{\circ} 20.35^{\prime} \mathrm{N}$ & $68^{\circ} 22.25^{\prime} \mathrm{W}$ & puff/tuft/bowtie & $+-/+-1+-$ & $\begin{array}{l}\text { dim-normal/dim-normal/dim- } \\
\text { normal }\end{array}$ \\
\hline 06 Oct 01 & EN361-5 & $30^{\circ} 6.42^{\prime} \mathrm{N}$ & $67^{\circ} 32.88^{\prime} \mathrm{W}$ & puff/tuft & $+-/+-$ & normal/dim-normal \\
\hline 07 Oct 01 & EN361-6 & $29^{\circ} 10.21^{\prime} \mathrm{N}$ & $64^{\circ} 43.528^{\prime} \mathrm{W}$ & puff/tuft & $+-1+-$ & dim-normal/dim-normal \\
\hline 06 Aug 03 & MP09-13 & $20^{\circ} 29.59^{\prime} \mathrm{N}$ & $157^{\circ} 41.32^{\prime} \mathrm{W}$ & puff/tuft & -- & normal/normal \\
\hline 07 Aug 03 & MP09-14 & $18^{\circ} 30.00^{\prime} \mathrm{N}$ & $157^{\circ} 00.00^{\prime} \mathrm{W}$ & puff & -- & normal \\
\hline 10 Aug 03 & MP09-16 & $19^{\circ} 32.49^{\prime} \mathrm{N}$ & $156^{\circ} 55.74^{\prime} \mathrm{W}$ & puff/tuft & $+-1--$ & normal/normal \\
\hline 11 Aug 03 & MP09-16 & $19^{\circ} 30.55^{\prime} \mathrm{N}$ & $156^{\circ} 55.74^{\prime} \mathrm{W}$ & puff/tuft & $+-1--$ & normal/normal \\
\hline 12 Aug 03 & MP09-17 & $19^{\circ} 31.23^{\prime} \mathrm{N}$ & $158^{\circ} 58.75^{\prime} \mathrm{W}$ & puff/tuft & $--1--$ & normal/normal \\
\hline 13 Aug 03 & MP09-17 & $19^{\circ} 30.10^{\prime} \mathrm{N}$ & $158^{\circ} 59.94^{\prime} \mathrm{W}$ & puff & +- & normal \\
\hline 14 Aug 03 & MP09-18 & $20^{\circ} 31.84^{\prime} \mathrm{N}$ & $160^{\circ} 59.81^{\prime} \mathrm{W}$ & puff/tuft & $--1+-$ & $\operatorname{dim} / \operatorname{dim}$ \\
\hline 15 Aug 03 & MP09-19 & $21^{\circ} 00.79^{\prime} \mathrm{N}$ & $158^{\circ} 59.70^{\prime} \mathrm{W}$ & puff/tuft & -- & dim/normal \\
\hline 16 Aug 03 & MP09-19 & $21^{\circ} 00.18^{\prime} \mathrm{N}$ & $158^{\circ} 59.69^{\prime} \mathrm{W}$ & puff/tuft & $--1--$ & $\mathrm{dim} /$ normal \\
\hline 17 Aug 03 & MP09-20 & $20^{\circ} 16.09^{\prime} \mathrm{N}$ & $156^{\circ} 31.72^{\prime} \mathrm{W}$ & puff/tuft & $+-1--$ & normal/normal \\
\hline 18 Aug 03 & MP09-21 & $20^{\circ} 15.61^{\prime} \mathrm{N}$ & $159^{\circ} 11.21^{\prime} \mathrm{W}$ & puff/tuft & $+-1+-$ & normal/dim \\
\hline 19 Aug 03 & MP09-22 & $19^{\circ} 06.67^{\prime} \mathrm{N}$ & $162^{\circ} 13.05^{\prime} \mathrm{W}$ & puff/tuft & $+-1+-$ & normal/dim \\
\hline 20 Aug 03 & MP09-22 & $19^{\circ} 06.29^{\prime} \mathrm{N}$ & $162^{\circ} 13.60^{\prime} \mathrm{W}$ & puff/tuft & $--1--$ & $\operatorname{dim} / \operatorname{dim}$ \\
\hline 21 Aug 03 & MP09-23 & $20^{\circ} 30.68^{\prime} \mathrm{N}$ & $161^{\circ} 30.27^{\prime} \mathrm{W}$ & puff/tuft & $--1--$ & normal/dim \\
\hline 07 Jan 07 & KM0701-5 & $12^{\circ} 26.11^{\prime} \mathrm{N}$ & $167^{\circ} 43.75^{\prime} \mathrm{W}$ & puff/tuft & $--1--$ & normal/dim-normal \\
\hline 10 Jan 07 & KM0701-8 & $5^{\circ} 38.86^{\prime} \mathrm{N}$ & $174^{\circ} 32.18^{\prime} \mathrm{W}$ & tuft & -- & dim-normal \\
\hline 11 Jan 07 & KM0701-9 & $3^{\circ} 14.40^{\prime} \mathrm{N}$ & $176^{\circ} 53.04^{\prime} \mathrm{W}$ & puff & -- & normal \\
\hline 12 Jan 07 & KM0701-10 & $0^{\circ} 22.02^{\prime} \mathrm{N}$ & $179^{\circ} 38.60^{\prime} \mathrm{W}$ & tuft & -- & normal \\
\hline 15 Jan 07 & KM0701-12 & $4^{\circ} 43.34^{\prime} \mathrm{S}$ & $174^{\circ} 43.85^{\prime} \mathrm{E}$ & puff & -- & normal \\
\hline 16 Jan 07 & KM0701-13 & $7^{\circ} 3.64^{\prime} \mathrm{S}$ & $172^{\circ} 18.98^{\prime} \mathrm{E}$ & tuft & -- & normal \\
\hline 17 Jan 07 & KM0701-14 & $9^{\circ} 15.03^{\prime} \mathrm{S}$ & $169^{\circ} 59.96^{\prime} \mathrm{E}$ & puff/tuft/bowtie & $--1--1--$ & dim-normal/normal/normal \\
\hline 19 Jan 07 & KM0701-14 & $9^{\circ} 15.01^{\prime} \mathrm{S}$ & $170^{\circ} 0.01^{\prime} \mathrm{E}$ & puff/tuft & $--1+-$ & normal/dim-normal \\
\hline 20 Jan 07 & KM0701-15 & $12^{\circ} 34.55^{\prime} \mathrm{S}$ & $169^{\circ} 51.55^{\prime} \mathrm{E}$ & tuft & -- & normal \\
\hline 21 Jan 07 & KM0701-16 & $15^{\circ} 53.63^{\prime} \mathrm{S}$ & $169^{\circ} 43.02^{\prime} \mathrm{E}$ & puff & -- & normal \\
\hline 22 Jan 07 & KM0701-17 & $19^{\circ} 13.95^{\prime} \mathrm{S}$ & $169^{\circ} 34.63^{\prime} \mathrm{E}$ & puff/tuft & $+-1+-$ & dim-normal/normal \\
\hline 23 Jan 07 & KM0701-19 & $21^{\circ} 37.42^{\prime} \mathrm{S}$ & $168^{\circ} 39.49^{\prime} \mathrm{E}$ & puff/tuft & $--1--$ & normal/normal \\
\hline 26 Jan 07 & KM0701-20 & $25^{\circ} 40.30^{\prime} \mathrm{S}$ & $165^{\circ} 25.03^{\prime} \mathrm{E}$ & $\mathrm{NA} /$ puff/tuft & $--/ \mathrm{NA} / \mathrm{NA}$ & normal/NA/NA \\
\hline 27 Jan 07 & KM0701-21 & $29^{\circ} 2.43^{\prime} \mathrm{S}$ & $164^{\circ} 20.26^{\prime} \mathrm{E}$ & puff/tuft & $--1+-$ & normal/normal \\
\hline 03 Feb 07 & KM0701-26 & $32^{\circ} 25.29^{\prime} \mathrm{S}$ & $159^{\circ} 5.33^{\prime} \mathrm{E}$ & puff/tuft & $--1+-$ & normal/dim-normal \\
\hline 07 Feb 07 & KM0701-28 & $30^{\circ} 15.51^{\prime} \mathrm{S}$ & $157^{\circ} 18.19^{\prime} \mathrm{E}$ & puff/tuft & $+-1+-$ & normal/dim-normal \\
\hline 08 Feb 07 & KM0701-29 & $29^{\circ} 45.56^{\prime} \mathrm{S}$ & $156^{\circ} 37.43^{\prime} \mathrm{E}$ & puff/tuft & $--1+-$ & normal/normal \\
\hline 09 Feb 07 & KM0701-30 & $28^{\circ} 45.68^{\prime} \mathrm{S}$ & $155^{\circ} 22.16^{\prime} \mathrm{E}$ & puff/tuft & $+-/ \mathrm{NA}$ & normal/NA \\
\hline
\end{tabular}

of DIP concentrations were plotted for each ELF label rating (Fig. 5). Trichodesmium colonies with little or no ELF labeling were found in stations from all cruises, spanning the full range of DIP concentrations (Fig. 5A). Samples with moderate levels of labeling spanned a moderate range of DIP: BDL-169 nmol L-1 (Fig. 5B). High levels of labeling were found only in samples from North Atlantic stations with DIP concentrations $<50 \mathrm{nmol} \mathrm{L}^{-1}$ (Fig. 5C). In a two-way ANOVA, DIP concentrations for stations with an ELF rating of '- -' were greater than DIP concentrations for stations with an ELF rating of ' +- ' or ' ++ ', significant at the $94 \%$ confidence level ( $p=0.0554$; Table 2).

Nitrogenase activity - Nitrogenase activity varied significantly between the basins (Table 3; Fig. 6). In the Pstressed western North Atlantic, mean nitrogenase activities measured during EN355 and EN361 were significantly higher than rates in both the North and South Pacific ( $p=$ $\left.5.35 \times 10^{-8}\right): 0.80 \pm 0.22 \mathrm{nmol} \mathrm{C}_{2} \mathrm{H}_{4} \mathrm{~h}^{-1}$ colony $^{-1}$ and 


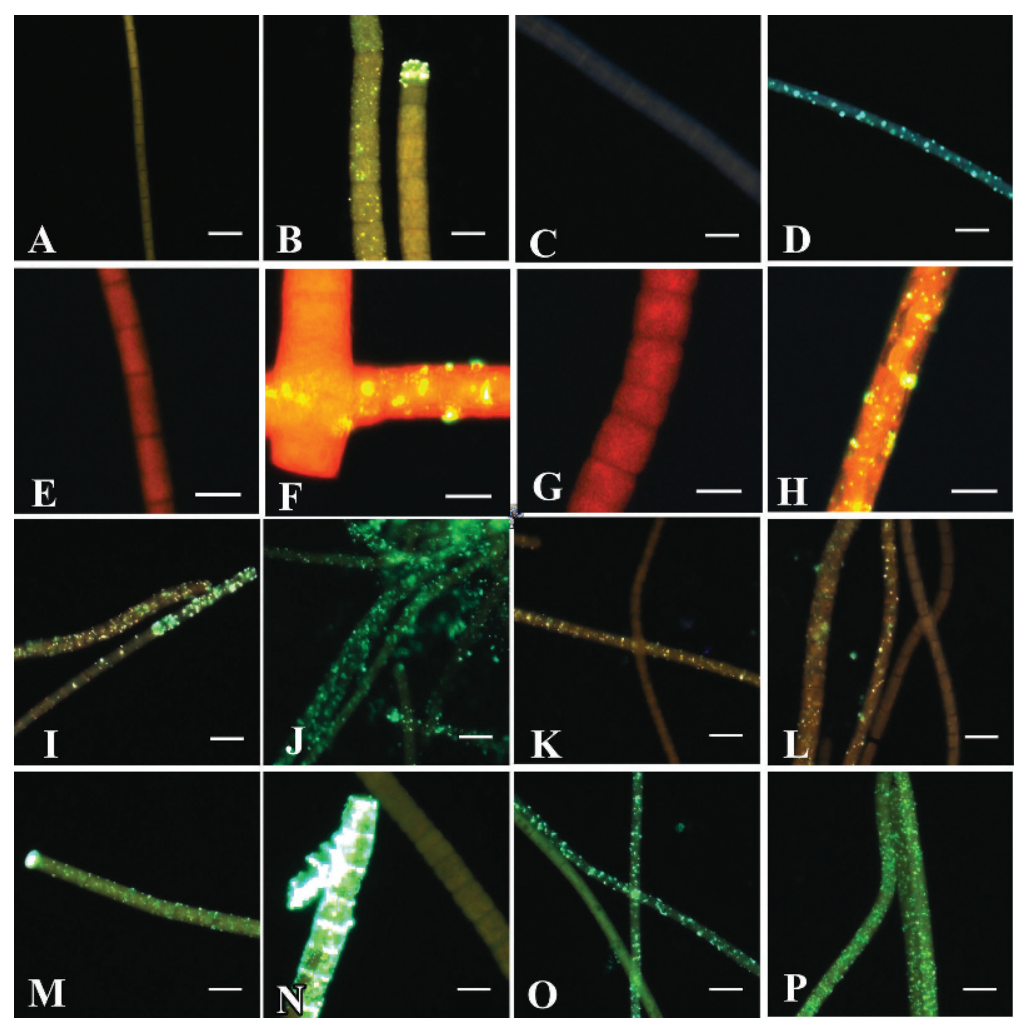

Fig. 3. Selected digital micrographs of ELF-assayed Trichodesmium from the four cruises: (A-D) MP09 during August 2003, in the North Pacific; (E-H) KM0701 during January and February 2007, across the west Pacific warm pool; and (I-L) EN355 during June 2001, and (M-P) EN361 during October 2001, in the western North Atlantic. White scale bars correspond to $10 \mu \mathrm{m}$. (A) Sta. MP09-16, 10 August 2003, tuft, '- -'; (B) Sta. MP09-16, 10 August 2003, puff, '+ -'; (C) Sta. MP09-22, 20 August 2003, puff, '- -'; (D) Sta. MP09-22, 19 August 2003, tuft, '+ -'; (E) Sta. KM0701-14, 17 January 2007, puff, '- - '; (F) Sta. KM0701-17, 22 January 2007, puff, '+ -'; (G) Sta. KM0701-26, 03 February 2007, puff, '- - '; (H) Sta. KM0701-26, 03 February 2007, tuft, ‘+ -'; (I) Sta. 6-6, 07 June 2001, '++ '; (J) Sta. 6-7, 09 June 2001, '+ -'; (K) Sta. 6-7, 09 June 2001, '+ -'; (L) Sta. 6-8, 11 June 2001, '+-'; (M) Sta. 10-1, 04 October 2001, puff, '+ -'; (N) Sta. 10-2, 05 October 2001, tuft, '++'; (O) Sta. 10-3, 05 October 2001, puff, '+ -'; (P) Sta. 10-5, 06 October 2001, puff, '十 -'.

$0.79 \pm 0.14 \mathrm{nmol} \mathrm{C}_{2} \mathrm{H}_{4} \mathrm{~h}^{-1}$ colony $^{-1}$ compared to $0.26 \pm$ $0.03 \mathrm{nmol} \mathrm{C}_{2} \mathrm{H}_{4} \mathrm{~h}^{-1}$ colony ${ }^{-1}$ (D. Capone pers. comm.) and $0.09 \pm 0.02 \mathrm{nmol} \mathrm{C}_{2} \mathrm{H}_{4} \mathrm{~h}^{-1}$ colony $^{-1}$, respectively (Fig. 6). For stations with nitrogenase activity measurements for both puff and tuft colonies, rates were generally greater for tuft colonies than puff colonies although the rates were not significantly different between colony morphs according to one-way ANOVA Tukey-Kramer tests $(p \geq 0.1355)$. There were two exceptions to this pattern. At Sta. KM0701-14, puff nitrogenase activity was greater than that of tufts but not significantly ( $p=0.2379$ ), and at Sta. KM0701-30 near Australia, the rate for tuft colonies was significantly greater than that of puff colonies $(p=0.0022)$.

\section{Discussion}

Trichodesmium is a source of new $\mathrm{N}$ in tropical and subtropical oceans around the world, but the factors limiting $\mathrm{N}_{2}$ fixation in Trichodesmium are not completely understood. The South Pacific in particular is an under- sampled region (Campbell et al. 2005). Our study investigated $\mathrm{P}$ stress and $\mathrm{N}_{2}$ fixation in Trichodesmium in three major ocean regions: the western North Atlantic, the North Pacific, and the western South Pacific. Our results show patterns of both higher $\mathrm{P}$ stress and higher $\mathrm{N}_{2}$ fixation rates in the western North Atlantic than in the Pacific.

During the 2001 western North Atlantic cruises, colonies of Trichodesmium showed more frequent and more complete ELF labeling than the Pacific samples in this study. This difference in ELF labeling is a qualitative indication of higher AP activity in the North Atlantic. The samples near Australia also showed more labeling than other regions of the South Pacific. In this region the MLD was shallower and the DIP concentrations were lower. Trichodesmium thrives in warm, stratified waters, and blooms are found in oligotrophic waters where the SST $\geq 25^{\circ} \mathrm{C}$ (Karl et al. 2002). However, supply of $\mathrm{P}$ to surface waters can be cut off by warming and stratification of surface layers. ELF is not quantitative, so finding a direct parametric correlation with DIP concentrations is not 

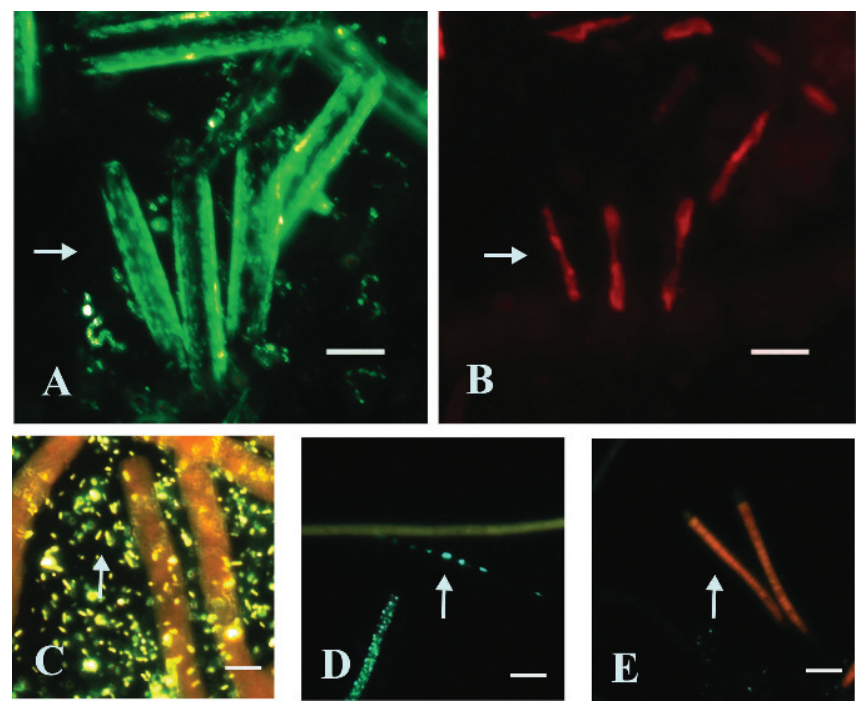

Fig. 4. Organisms associated with Trichodesmium colonies. White arrows indicate the organisms and white scale bars correspond to $10 \mu \mathrm{m}$. (A) ELF-labeled pennate diatoms (Sta. MP09-17); (B) the same pennate diatoms in (A) viewed under a chlorophyll filter; (C) ELF-labeled heterotrophic bacteria (Sta. MP09-16, 11 Aug 03, puff); (D) ELF-labeled cyanobacterium Plectonema sp. (Sta. MP09-19, 15 Aug 03, puff); (E) $\mathrm{N}_{2}$-fixing cyanobacterium Calothrix sp. (Sta. MP09-23, 21 Aug 03, tuft).

possible. However, by examining the range of DIP concentrations associated with the different levels of ELF label, it is apparent that higher labeling is associated with lower DIP concentrations. This is in contrast to Webb et al. (2007), where they found no significant relationship between ELF labeling and DIP during a transect in the western Equatorial to western South Atlantic. In our study, we had more data points of ELF and a broader range of DIP than Webb et al. (2007; 5-320 nmol L ${ }^{-1}$ compared to $10-120 \mathrm{nmol} \mathrm{L}^{-1}$ ), and this breadth of data may have enabled us to find a significant relationship between DIP and ELF labeling. Also in contrast to Webb et al. (2007), we did not see consistent differences in labeling between puff and tuft colonies. In a study of the North and South Atlantic subtropical gyres, surface-water column AP activity was higher and DIP was lower in the North than the South Atlantic (Mather et al. 2008). AP activity in the NPSG measured during cruise MP09 was 4.4 times lower than AP activity in the North Atlantic (Sohm et al. 2008), which is consistent with our ELF-based observations. The difference in AP activity observed by ELF labeling and hydrolytic rates among these regions suggests that the

Table 2. Two-way ANOVA on dissolved inorganic phosphate concentrations among enzyme-labeled fluorescence (ELF) ratings and ocean basins.

\begin{tabular}{lrrr}
\hline \hline \multicolumn{1}{c}{ Factor } & \multicolumn{1}{c}{$F$} & \multicolumn{1}{c}{ Groupings } \\
\hline ELF rating & 3.04 & 0.0554 & '++' and '+ + '; ' -- ' \\
Ocean basin & 11.55 & 0.0001 & $\begin{array}{l}\text { North Atlantic; North and South } \\
\text { Pacific }\end{array}$ \\
\hline
\end{tabular}
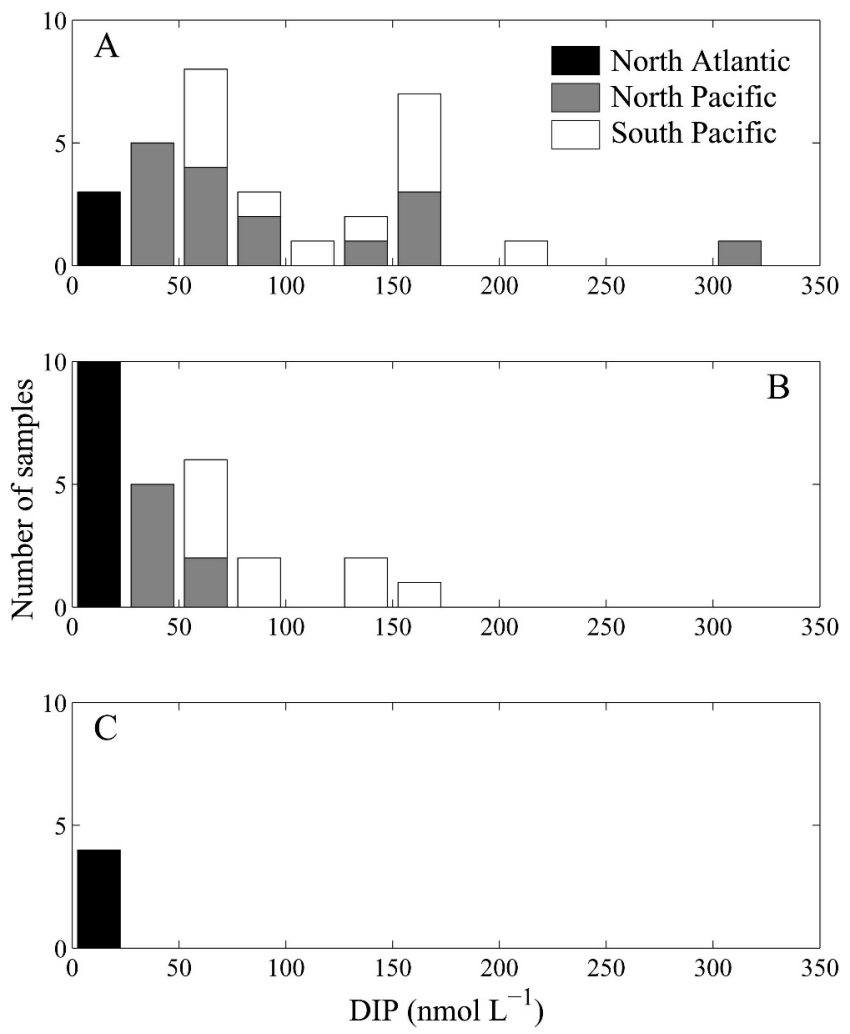

Fig. 5. Histogram of binned surface DIP concentrations (nmol L-1) separated by ELF label ratings: (A) ' - -', (B) '+ -', (C) ' ++ '. Colors represent ocean basin: North Atlantic (black), North Pacific (gray), and South Pacific (white). Bin width is $25 \mathrm{nmol} \mathrm{L}^{-1}$.

Atlantic populations were generally more P-stressed than those in the Pacific.

In addition to AP activity, indicators used to determine $\mathrm{P}$ stress or potential limitation include DIP concentrations, maximum uptake rate of $\mathrm{PO}_{4}^{3-}\left(V_{\max }\right)$, cellular $\mathrm{N}: \mathrm{P}$ ratios, and turnover times of DIP. Results from these metrics used in the tropical and subtropical Atlantic and Pacific Oceans are consistent with our observations of AP activity. The critical concentration of DIP for Trichodesmium growth has been determined to be $9 \mathrm{nmol} \mathrm{L}^{-1}$ (Moutin et al. 2005). Although there is some overlap, Atlantic DIP concentrations are typically lower than this critical value while Pacific concentrations are typically higher (Table 3; Wu et al. 2000). The $V_{\max }$ of $\mathrm{PO}_{4}^{3-}$ uptake by Trichodesmium colonies measured during a cruise in the North Atlantic was four times more than that of the North Pacific during cruise MP09 (Sohm et al. 2008). Concentrations of DIP in the Sargasso Sea region of the Atlantic are one to two orders of magnitude lower than those in the subtropical North Pacific (Wu et al. 2000). Molar ratios of cellular $\mathrm{N}$ : P may indicate nutrient limitation and/or storage. The reference Redfield ratio of $\mathrm{N}: \mathrm{P}$ is 16 . The $\mathrm{P}$ limitation of growth in Trichodesmium begins at N : $\mathrm{P}$ of 40-50 (Kustka et al. 2003), and in P-restricted cultures, N:P can reach $\geq 90$ (White et al. 2006). Trichodesmium N:P ratios averaged 40.1 \pm 2.53 during the North Pacific MP09 cruise while they ranged from 60 in the west to 30 in the 
Table 3. Comparison of the North Pacific, western South Pacific, and western North Atlantic (an overview of parameters in each basin, not a comprehensive regional survey).

\begin{tabular}{|c|c|c|c|c|c|c|}
\hline Measurement & N. Pacifict & Refs* & S. Pacifict & Refs* & N. Atlantic $\dagger$ & Refs* \\
\hline \multicolumn{7}{|l|}{ Dissolved inorganic phosphate $\left(\mathrm{nmol} \mathrm{L}^{-1}\right)$} \\
\hline Transect & $100-324 a ; 26-108^{b}$ & $1 ; 2$ & $131-219 a ; 61-103 a, c$ & $1 ; 1$ & BDL-25 & 1 \\
\hline Published values & $3.0-191.3^{\mathrm{d}}$ & 3 & $80-218$ & 4 & $0.2-1.0$ & 5 \\
\hline Enzyme-labeled fluorescence &,--+- & 1 &,--+- & 1 &,,--+-++ & 1 \\
\hline MUF-P hydrolyzed $\left.(\mu \mathrm{g} \text { Chl } a)^{-1} \mathrm{~h}^{-1}\right)$ & $0.01-2.09 \mathrm{~b}, \mathrm{e}$ & 6 & $0.65-13.1^{\mathrm{f}}$ & 7 & $30-240 \mathrm{~g} ; 3.1-10.3$ & $7 ; 8$ \\
\hline $\begin{array}{l}\mathrm{N}_{2} \text { fixation, areal depth-integrated } \\
\text { estimated from acetylene reduction } \\
\left(\mathrm{mmol} \mathrm{N} \mathrm{m} \mathrm{N}^{-2} \mathrm{yr}^{-1}\right)\end{array}$ & $31 \pm 18$ & 12 & & & $87.2 \pm 13.9 \mathrm{~g}, \mathrm{~h}$ & 13 \\
\hline
\end{tabular}

$* 1=$ This study; $2=\mathrm{K}$. Björkman pers. comm.; $3=$ Hawaii Ocean Time-series; $4=$ Campbell et al. $(2005) ; 5=\mathrm{Wu}$ et al. $(2000) ; 6=\mathrm{J}$. Sohm pers. comm.; 7 = Mulholland et al. (2002); $8=$ Sohm and Capone (2006); $9=$ White et al. (2006); $10=$ Krauk et al. (2006); $11=$ D. Capone pers. comm.; 12= Karl et al. (1997); 13 = Capone et al. (2005).

$\dagger^{\mathrm{a}}=$ KM0701 data; $\mathrm{b}=$ MP09 data; ${ }^{\mathrm{c}}=$ observations east of Australia; $\mathrm{d}=$ HOT low-level phosphate data, December 1988-December 2004, 0-50 m, calculated assuming water density of $1.025 \mathrm{~kg} \mathrm{~L}^{-1}$; e $=$ data not normalized to (MUF-P) as reported in Sohm et al. (2008); $\mathrm{f}_{=}$observations north of Australia; $\mathrm{g}=$ observations in western North Atlantic near the Caribbean; $\mathrm{h}=$ calculated from reported average areal depth integrated rate of $239 \pm$ $38 \mu \mathrm{mol} \mathrm{N} \mathrm{m}-2 \mathrm{~d}^{-1}$

east in the subtropical North Atlantic in 2000, indicating more P limitation in the western North Atlantic (Krauk et al. 2006). Turnover time is calculated as the inventory of a nutrient divided by its uptake rate and can be considered as the period it would take to deplete a nutrient if input was halted (Ammerman et al. 2003). Short turnover times of DIP $\left(\tau_{D I P}\right)$ result from low inventory and/or high uptake rates and can indicate low DIP availability. At the Climax station in the North Pacific, $\tau_{D I P}$ was $48 \mathrm{~h}$ in the summer (Björkman et al. 2000). In contrast, Sargasso Sea $\tau_{D I P}$ was measured to be around $9 \mathrm{~h}$ (Cotner et al. 1997). Turnover times of DIP in the South Pacific near New Caledonia varied widely and decreased from $468 \mathrm{~h}$ in the winter to $4 \mathrm{~h}$ in the early autumn, indicating $\mathrm{P}$ depletion after the stratification of the water column in the summer (Van Den Broeck et al. 2004). These P stress indicators are consistent with higher potential for $\mathrm{P}$ limitation in the subtropical western North Atlantic than the subtropical North and South Pacific with a region of summer P limitation in the South Pacific near New Caledonia.

Colonies used in the ELF assay were chosen in an attempt to represent the community, but a number of issues arise because of the small sample size. Field populations of Trichodesmium have a range of characteristics including nutrient history, species, and degree of senescence that might not be reflected in two colonies per morphology per

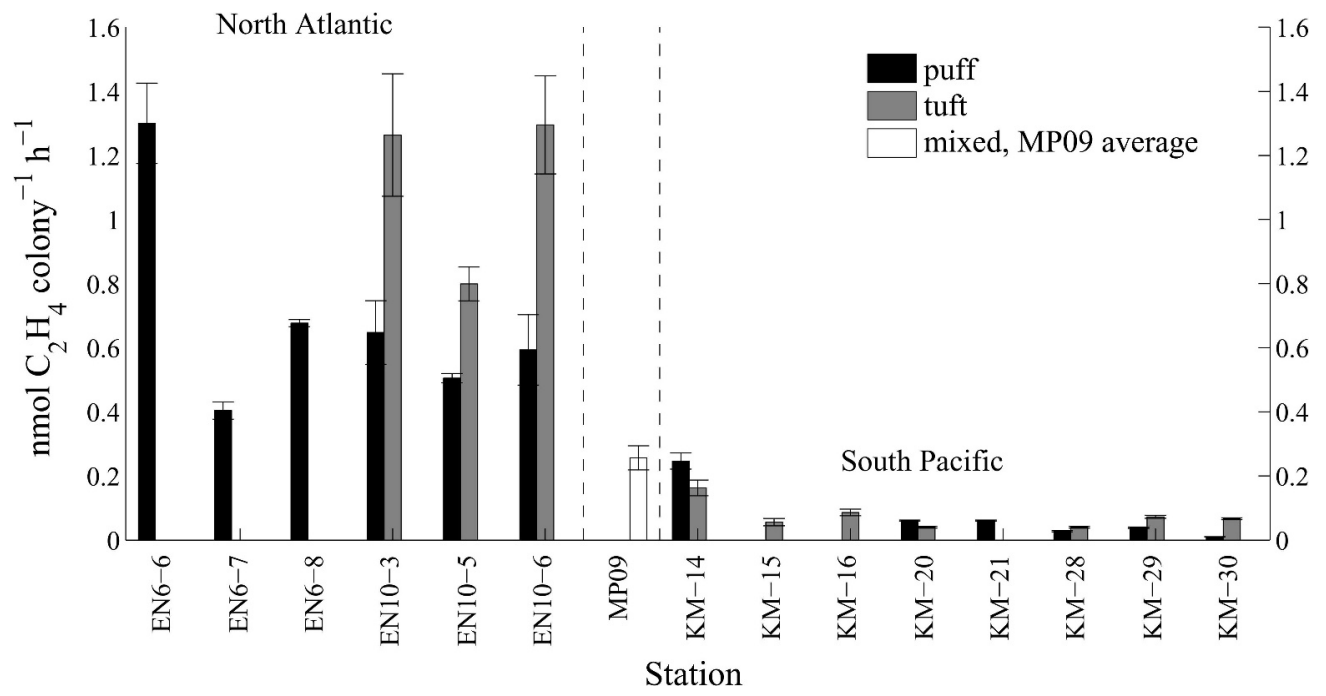

Fig. 6. Bar plot of nitrogenase activity $\left(\mathrm{nmol} \mathrm{C}_{2} \mathrm{H}_{4}\right.$ produced colony $\left.{ }^{-1} \mathrm{~h}^{-1}\right)$ for each station. Error bars show standard error of the mean. Data are separated by puffs (black), tufts (gray), or mixed puffs and tufts (white). The North Pacific is represented by the average rates for MP09 Sta. 14-22 (D. Capone pers. comm.). Ocean basins are separated by vertical dotted lines. 
station. ELF labeling varies within a sample, a colony, or even along a filament. Although colonies of the same morphology were targeted, filaments observed on the ELF slides were from a variety of Trichodesmium species based on cell width and length. Samples also displayed a range of phycobiliprotein autofluorescence. The dim filaments observed may be due to senescent colonies, bleaching, or fading. In some cases, labeling on a slide was higher on dim filaments than normal filaments, which may indicate elevated AP activity in senescent colonies or in heterotrophic bacteria associated with these colonies in some cases. Although the colonies picked for the ELF assay may not capture the diversity of field populations, they do give useful snapshots of the state of the community.

A variety of organisms including bacteria, fungi, diatoms, dinoflagellates, chrysophytes, ciliates, amoebae, hydroids, and crustacean larvae can be enriched by $2-5$ orders of magnitude in association with Trichodesmium colonies (Sheridan et al. 2002). Hydrolysis rates measured on Trichodesmium colonies may reflect the activity of the whole community rather than Trichodesmium-specific activity (Dyhrman et al. 2002; Webb et al. 2007). The activity of AP from associated organisms such as pennate diatoms, heterotrophic bacteria, and Plectonema may result in an indirect source of DIP that can be utilized by Trichodesmium. The presence of AP in these microorganisms may also result in the overestimation of Trichodesmium AP activity measured through bulk assays. With ELF, AP activity can be visually localized to specific cells.

In addition to AP measurements, $\mathrm{N}_{2}$ fixation rates attributed to Trichodesmium may be influenced by the diazotrophs tentatively identified as Plectonema sp. and Calothrix sp. found in close association with Trichodesmium colonies. Both of these cyanobacteria occupy a wide variety of habitats, including marine. The long, thin filaments of nonheterocystous Plectonema are found in Trichodesmium colonies around the world (Siddiqui et al. 1992). Calothrix is identified by its terminal heterocyst and tapering trichome (Waterbury 2006), and is found in the upper intertidal zone (Whitton and Potts 1982) and as an epiphyte of the pelagic diatom Chaetoceros (Foster and Zehr 2006). Although Plectonema is known to fix $\mathrm{N}_{2}$ only in lowered oxygen tension (Rippka et al. 1979), both Plectonema and Calothrix may be contributing to $\mathrm{N}_{2}$ fixation rates measured from Trichodesmium colonies.

During the four cruises analyzed in this study, Trichodesmium colony-based $\mathrm{N}_{2}$ fixation rates were significantly higher in the subtropical North Atlantic than in the tropical and subtropical North and South Pacific. North Atlantic values averaged $0.80 \pm 0.12 \mathrm{nmol} \mathrm{C}_{2} \mathrm{H}_{4} \mathrm{~h}^{-1}$ colony $^{-1}$ while Pacific values averaged $0.13 \pm 0.02 \mathrm{nmol}_{2} \mathrm{C}_{2} \mathrm{H}_{4} \mathrm{~h}^{-1}$ colony $^{-1}$. As in Webb et al. (2007), tuft colonies generally had higher per colony rates than puffs; however, the difference between colony morphologies was not significant in our study with one exception. For comparison, literature values of $\mathrm{N}_{2}$ fixation rates measured by acetylene reduction averaged $87 \pm 14 \mathrm{mmol} \mathrm{N} \mathrm{m}-2 \mathrm{yr}^{-1}$ in the western North Atlantic from 1994 to $2003\left(1.6 \times 10^{12} \mathrm{~mol} \mathrm{~N} \mathrm{yr}^{-1}\right.$ over $17.8 \times 10^{6} \mathrm{~km}^{2}$; Capone et al. 2005), while the North Pacific averaged $31 \pm 18 \mathrm{mmol} \mathrm{N} \mathrm{m}^{-2} \mathrm{yr}^{-1}$ from 1990 to
1992 (Karl et al. 1997). Biogeochemical estimates of the annual input of new $\mathrm{N}$ by $\mathrm{N}_{2}$ fixation were $2.0 \times 10^{12} \mathrm{~mol}$ $\mathrm{N} \mathrm{yr}-1$, or $72 \mathrm{mmol} \mathrm{N} \mathrm{m}^{-2} \mathrm{yr}^{-1}$ in the subtropical North Atlantic (Gruber and Sarmiento 1997) and $4 \pm 1 \times$ $10^{12} \mathrm{~mol} \mathrm{~N} \mathrm{yr}^{-1}$, or $39 \pm 9 \mathrm{mmol} \mathrm{N} \mathrm{m} \mathrm{Nr}^{-1}$ in the tropical and subtropical Pacific (Deutsch et al. 2001). In a global biogeochemical elemental cycling ocean model, $\mathrm{N}_{2}$ fixation rates averaged $18 \mathrm{mmol} \mathrm{N} \mathrm{m}^{-2} \mathrm{yr}^{-1}$ in the tropical and subtropical Atlantic and $11 \mathrm{mmol} \mathrm{N} \mathrm{m}^{-2} \mathrm{yr}^{-1}$ in the tropical and subtropical Pacific (Moore and Doney 2007). Our nitrogenase activity measurements are in congruence with the pattern found in these estimates; $\mathrm{N}_{2}$ fixation rates are higher in the tropical and subtropical North Atlantic than in the tropical and subtropical Pacific.

The difference in $\mathrm{N}_{2}$ fixation rates between the Atlantic and Pacific Oceans may be due to disparate nutrient limitation regimes. $\mathrm{N}_{2}$ fixation in the western North Atlantic is more P-limited than Fe-limited (Wu et al. 2000; Sañudo-Wilhelmy et al. 2001; Moore et al. 2004). When Trichodesmium cells have met their Fe cell quota, $\mathrm{N}_{2}$ fixation correlates with cellular P quotas (Sañudo-Wilhelmy et al. 2001). In the western Equatorial and South Atlantic, $\mathrm{N}_{2}$ fixation in shipboard incubations was higher when P stress was relieved by the addition of DIP than in control or $\mathrm{Fe}$ addition incubations (Webb et al. 2007). Trichodesmium AP activity is higher in the North Atlantic than in the Pacific Ocean (Table 3; Mulholland et al. 2002; Sohm and Capone 2006; Sohm et al. 2008), and this difference is reflected by the visualization of AP activity through ELF (Table 3; Figs. 1, 3).

In contrast, $\mathrm{N}_{2}$ fixation in the North Pacific may be limited by factors other than P. The North Pacific receives less Fe-rich dust input than the North Atlantic (Fung et al. 2000), and Fe is necessary for Trichodesmium growth and the enzyme nitrogenase used in $\mathrm{N}_{2}$ fixation. In the South Pacific, regions near New Caledonia and Australia receive Fe from continental margins and Australian dust (Moore and Braucher 2008). Fe stimulates the growth of diazotrophs, drawing down P (Karl 2002; Mather et al. 2008), so Fe-rich areas such as the western North Atlantic and western South Pacific near Australia are more likely to be P-limited. In a coupled biogeochemistry ecosystem circulation model, diazotrophs were limited by $\mathrm{P}$ in the Atlantic and by $\mathrm{Fe}$ in the Pacific, and increasing $\mathrm{Fe}$ inputs in the model increased $\mathrm{N}_{2}$ fixation in the tropics and subtropics (Moore et al. 2004). These data suggest that $\mathrm{N}_{2}$ fixation rates of Trichodesmium in the western North Atlantic and in the South Pacific near Australia are limited by $\mathrm{P}$ while the Pacific subtropical gyres may be limited by Fe or colimited by $\mathrm{Fe}$ and $\mathrm{P}$.

Although $\mathrm{P}$ limitation may be alleviated by the use of DOP by Atlantic Trichodesmium, Fe limitation in Pacific populations cannot be alleviated by the use of an alternative pool (Webb et al. 2007; Mather et al. 2008). In a comparison of the North and South Atlantic, DIP released from AP activity in the P-stressed North Atlantic supported up to $30 \%$ of primary production and carbon fixation rates there were comparable to rates in the Preplete South Atlantic (Mather et al. 2008). Fe may be the proximal limiting nutrient according to Leibig's law while $\mathrm{P}$ 
may be the ultimate limiting nutrient, controlling productivity over long timescales (Tyrrell 1999). Additional assessments of Trichodesmium $\mathrm{P}$ and $\mathrm{Fe}$ physiology in open-ocean gyres are necessary to elucidate nutrient controls on $\mathrm{N}_{2}$ fixation, but our study supports previous observations that the North Atlantic is P-limited while the Pacific is likely to be Fe-limited. This study underscores the contrasting importance of $\mathrm{P}$ (and likely Fe) to the activity of the key diazotroph Trichodesmium in different ocean basins.

\section{Acknowledgments}

We thank J. Sohm and K. Björkman for MP09 data and comments on drafts for this manuscript, J. Waterbury for assistance at sea for EN355 and EN361, D. Masten and S. Becker for dissolved inorganic phosphorus (DIP) analysis for EN355 and EN361, and J. Jennings for DIP analysis for KM0701. Special thanks to V. Starczyk for assistance in the statistical analysis of the enzyme-labeled fluorescence (ELF) data. We wish to acknowledge two anonymous reviewers whose contributions improved this manuscript. We also express our gratitude to the captain, crews, and named chief scientists of the following cruises: Z. Johnson and E. Zinser of the R/V Kilo Moana cruise KM0701, D. Capone of the R/V Revelle cruise MP09 (as well as our collaborators involved in the Marine Nitrogen Transformation (MANTRA) project), and H. Sosik and R. Olson of the R/V Endeavor cruises EN355 and EN361. This work was supported from the National Science Foundation (NSF) Biocomplexity Program Grant (OCE-0323332); the NSF Biological Oceanography Program (OCE-0220945); NSF grants to EAW (OCE0220945 and OCE-0623499); Woods Hole Oceanographic Institution (WHOI) fellowship to EAW, National Defense Science and Engineering Graduate (NDSEG) fellowship to PDC; and the Center for Microbial Oceanography Research and Education (CMORE), an NSF Science and Technology Center (EF-0424599).

\section{References}

Ammerman, J. W., R. R. Hood, D. A. Case, and J. B. Cotner. 2003. Phosphorus deficiency in the Atlantic: An emerging paradigm in oceanography. EOS 84: 165-170.

Berman-Frank, I., J. T. Cullen, Y. Shaked, R. M. Sherrell, AND P. G. FALKOWSKI. 2001. Iron availability, cellular iron quotas, and nitrogen fixation in Trichodesmium. Limnol. Oceanogr. 46: 1249-1260.

Buörkman, K., A. L. Thomson-Bulldis, and D. M. Karl. 2000. Phosphorus dynamics in the North Pacific subtropical gyre. Aquat. Microb. Ecol. 22: 185-198.

Breitbarth, E., M. M. Mills, G. Friedrichs, and J. Laroche. 2004. The Bunsen gas solubility coefficient of ethylene as a function of temperature and salinity and its importance for nitrogen fixation assays. Limnol. Oceanogr. Methods 2: $282-288$.

Campbell, L., E. J. Carpenter, J. P. Montoya, A. B. Kustka, AND D. G. CAPONE. 2005. Picoplankton community structure within and outside a Trichodesmium bloom in the southwestern Pacific Ocean. Vie Milieu 55: 185-195.

CAPone, D. G., AND others. 2005. Nitrogen fixation by Trichodesmium spp.: An important source of new nitrogen to the tropical and subtropical North Atlantic Ocean. Glob. Biogeochem. Cycles 19: GB2024, doi:10.1029/2004GB002331.

_, AND J. P. Montoya. 2001. Nitrogen fixation and denitrification, In J. Paul [ed.], Methods in marine microbiology. Methods Microbiol 30, Academic.
, J. Zehr, H. Paerl, B. Bergman, and E. J. Carpenter. 1997. Trichodesmium: A globally significant marine cyanobacterium. Science 276: 1221-1229.

Coles, V. J., R. R. Hood, M. Pascual, and D. G. Capone. 2004. Modeling the impact of Trichodesmium and nitrogen fixation in the Atlantic Ocean. J. Geophys. Res. 109: C06007, doi:10.1029/2002JC001754.

Cotner, J. B., J. W. Ammerman, E. R. Peele, and E. Bentzen. 1997. Phosphorus-limited bacterioplankton growth in the Sargasso Sea. Aquat. Microb. Ecol. 13: 141-149.

Deutsch, C., N. Gruber, R. M. Key, and J. L. Sarmiento. 2001. Denitrification and $\mathrm{N}_{2}$ fixation in the Pacific Ocean. Glob. Biogeochem. Cycles 15: 483-506.

Dugdale, R. C., And J. J. Goering. 1967. Uptake of new and regenerated forms of nitrogen in primary productivity. Limnol. Oceanogr. 12: 196-206.

Dyhrman, S. T., E. A. Webb, D. A. Anderson, J. W. Moffett, And J. B. Waterbury. 2002. Cell-specific detection of phosphorus stress in Trichodesmium from the Western North Atlantic. Limnol. Oceanogr. 47: 1832-1836.

Eppley, R. W., And B. J. Peterson. 1979. Particulate organic matter flux and planktonic new production in the deep ocean. Nature 282: 677-680.

Foster, R. A., AND J. P. Zehr. 2006. Characterization of diatomcyanobacteria symbioses on the basis of nifH, het $R$ and $16 \mathrm{~S}$ rRNA sequences. Environ. Microbiol. 8: 1913-1925, doi:10.1111/j.1462-2920.2006.01068.x.

Fung, I. Y., S. K. Meyn, I. Tegen, S. C. Doney, J. G. John, And J. K. B. Bishop. 2000. Iron supply and demand in the upper ocean. Glob. Biogeochem. Cycles 14: 281-295.

González-Gil, S., B. A. Keafer, R. V. M. Jovine, A. Aguilera, S. Lu, And D. M. Anderson. 1998. Detection and quantification of alkaline phosphatase in single cells of phosphorusstarved marine phytoplankton. Mar. Ecol. Prog. Ser. 164: 21-35.

Gruber, N., AND J. SARmiento. 1997. Global patterns of marine nitrogen fixation and denitrification. Glob. Biogeochem. Cycles 11: 235-266.

Hood, R. R., A. M. Michaels, and D. G. Capone. 2000. Answers sought to the enigma of marine nitrogen fixation. EOS Trans. Am. Geophys. Union 81: 133, 138-139.

Karl, D., R. Letelier, L. Tupas, J. Dore, J. Christian, and D. Hebel. 1997. The role of nitrogen fixation in biogeochemical cycling in the subtropical North Pacific Ocean. Nature 388: 533-538.

, AND OTHERS. 2002. Dinitrogen fixation in the world's oceans. Biogeochem. 57-58: 47-98.

KarL, D. M. 2002. Nutrient dynamics in the deep blue sea. Trends Microbiol. 10: 410-418.

Krauk, J. M., T. A. Villareal, J. A. Sohm, J. P. Montoya, and D. G. CAPOnE. 2006. Plasticity of N:P ratios in laboratory and field populations of Trichodesmium spp. Aquat. Microb. Ecol. 42: $243-253$.

Kustka, A. B., S. A. Sañudo-Wilhelmy, E. J. Carpenter, D. CAPONE, J. Burns, AND W. G. Sunda. 2003. Iron requirements for dinitrogen- and ammonium-supported growth in cultures of Trichodesmium (IMS101): Comparison with nitrogen fixation rates and iron:carbon ratios of field populations. Limnol. Oceanogr. 48: 1869-1884.

Mather, R. L., AND others. 2008. Phosphorus cycling in the North and South Atlantic Ocean subtropical gyre. Nat. Geosci. 1: 439-443.

Mills, M., C. Ridame, M. Davey, J. La Roche, and R. J. Geider. 2004. Iron and phosphorus co-limit nitrogen fixation in the eastern tropical North Atlantic. Nature 429: 292-294. 
Moore, J. K., And O. Braucher. 2008. Sedimentary and mineral dust sources of dissolved iron to the world ocean. Biogeosci. 5: 631-656.

, AND S. C. Doney. 2007. Iron availability limits the ocean nitrogen inventory stabilizing feedbacks between marine denitrification and nitrogen fixation. 2007. Glob. Biogeochem. Cycles 21: GB2001, doi:10.1029/2006GB002762. , AND K. LindSAY. 2004. Upper ocean ecosystem dynamics and iron cycling in a global three-dimensional model. Glob. Biogeochem. Cycles 18: GB4028, doi:10.1029/ 2004GB002220.

Moutin, T., N. Van Den Broeck, B. Beker, C. Dupouy, P. Rimmelin, And A. Le Bouteiller. 2005. Phosphate availability controls Trichodesmium spp. biomass in the SW Pacific Ocean. Mar. Ecol. Prog. Ser. 297: 15-21.

Mulholland, M. R., S. Floge, E. J. Carpenter, and D. G. CAPONE. 2002. Phosphorus dynamics in cultures and natural populations of Trichodesmium spp. Mar. Ecol. Prog. Ser. 239: 45-55.

Rippka, R., J. Deruelles, J. B. Waterbury, M. Herdman, and R. Y. Stanier. 1979. Generic assignments, strain histories, and properties of pure cultures of cyanobacteria. J. Gen. Microbiol. 111: 1-61.

Sañudo-Wilhelmy, S. A., And others. 2001. Phosphorus limitation of nitrogen fixation by Trichodesmium in the central Atlantic Ocean. Nature 411: 66-69.

Sheridan, C. C., D. K. Steinberg, and G. W. Kling. 2002. The microbial and metazoan community associated with colonies of Trichodesmium spp. : A quantitative survey. J. Plankton Res. 24: 913-922.

Siddiqui, P. J. A., B. Bergman, and E. J. Carpenter. 1992. Filamentous cyanobacterial associates of the marine planktonic cyanobacterium Trichodesmium. Phycologia 31: 326-337.

Sohm, J. A., And D. G. CAPOnE. 2006. Phosphorus dynamics of the tropical and subtropical north Atlantic: Trichodesmium spp. versus bulk plankton. Mar. Ecol. Prog. Ser. 317: 21-28.

, C. Mahaffey, and D. G. Capone. 2008. Assessment of relative phosphorus limitation of Trichodesmium spp. in the North Pacific, North Atlantic, and the north coast of Australia. Limnol. Oceanogr. 53: 2495-2502.
Stinl, A., U. Sommer, And A. F. Post. 2001. Alkaline phosphatase activities among populations of the colonyforming diazotrophic cyanobacterium Trichodesmium spp. (Cyanobacteria) in the Red Sea. J. Phycol. 37: 310-317.

Tyrrell, T. 1999. The relative influences of nitrogen and phosphorus on oceanic primary production. Nature 400: 525-531.

Van Den Broeck, N., T. Moutin, M. Rodier, and A. Le BOUTEILLER. 2004. Season variations of phosphate availability in the SW Pacific Ocean near New Caledonia. Mar. Ecol. Prog. Ser. 268: 1-12.

Waterbury, J. B. 2006. The cyanobacteria-isolation, purification and identification, In M. Dworkin, S. Falkow, E. Rosenberg, K. Schleifer and E. Stackebrandt [eds.], The prokaryotes, 3rd ed. Springer, doi:10.1007/0-387-30744-3-38.

Webb, E. A., R. Wisniewski Jakuba, J. W. Moffett, and S. T. Dyhrman. 2007. Molecular assessment of phosphorus and iron physiology in Trichodesmium populations from the western Central and western South Atlantic. Limnol. Oceanogr. 52: 2221-2232.

White, A. E., Y. H. Spitz, D. M. Karl, and R. M. Letelier. 2006. Flexible elemental stoichiometry in Trichodesmium spp. and its ecological implications. Limnol. Oceanogr. 51: $1777-1790$

Whitton, B. A., And M. Potts. 1982. Marine littoral, In N. G. Carr and B. A. Whitton [eds.], The biology of cyanobacteria. Bot. Monogr. 19, Univ. California Press.

Wu, J., W. Sunda, E. A. Boyle, And D. M. Karl. 2000. Phosphate depletion in the western North Atlantic Ocean. Science 289: 759-762.
Associate editor: John Albert Raven

Received: 18 July 2008 Accepted: 10 February 2009 Amended: 06 April 2009 